\title{
KARST AND WORLD HERITAGE STATUS
}

\author{
KRAS IN STATUS SVETOVNE DEDIŠČINE
}

\author{
Elery HAMILTON-SMITH ${ }^{1}$
}

\begin{abstract}
UDK 502.13:551.44(100)

001:061.1(100):551.44

Elery Hamilton-Smith: Karst and World Heritage Status

Approximately 50 karst sites are now inscribed on the World Heritage Register, but many of these are inscribed on the basis of their non-karst values. Karst systems, of course, have a very wide range of values in themselves, including their remarkable biodiversity and their cultural significance, sometimes spanning many thousands of years. Today, the World Heritage Committee and UNESCO have asked that consideration be given to determining both a strategy for the nomination of new sites and a basis for priority setting in the selection of potential sites. This paper reviews current trends and emerging new patterns in World Heritage selection, assessment and management, then summarises the values of current karst WHAs in the European region.

Key words: UNESCO, Karst World Heritage, World Heritage selection, Europe.
\end{abstract}

Izvleček

UDC 502.13:551.44(100)

001:061.1(100):551.44

Elery Hamilton-Smith: Kras in status svetovne dediščine

Trenutno vsebuje seznam svetovne dediščine okoli 50 kraških krajev, toda precej jih je bilo vpisanih v seznamu zaradi drugih, »nekraških" posebnosti. Kraški sistemi imajo zelo širok razpon vrednosti sami po sebi, vključno njihovo izrazito biološko raznovrstnost in kulturni pomen, ki lahko obsega cela tisočletja. Danes želita tako Odbor za svetovno dediščino kot UNESCO, da bi določili tako strategijo za imenovanje novih krajev kot tudi osnove za določanje prednosti možnih krajev za vpis. Prispevek daje pregled preko trenutnih smeri in novih vzorcev, ki se pojavljajo pri izboru, ocenjevanju in imenovanju svetovne dediščine, ter povzema pomen trenutne kraške svetovne dediščine v Evropi.

Ključne besede: UNESCO, kraška svetovna dediščina, način izbora svetovne dediščine, Evropa.

\section{A HISTORICAL INTRODUCTION}

There has always been a sense of heritage in the passing on of lands and buildings from one generation to the next; as major public lands became collective or national properties, so they too were formally passed from generation to generation. Some lands and buildings were seen as being sacred, and often recognised across many nations. There were also places that were preserved for the rich and powerful to use as their exclusive hunting grounds. Others were recognised as places of special beauty, and they too may have been set aside as nature preserves in their own country.

The values and interests underlying the preservation of these many sites started to come together at a world level following World War II. Some of this was probably due to specific events, such as the virtual destruction of the City of Dresden, which heightened awareness of what might be lost if we failed to pay proper respect to important places. This was finally crystallised in 1960 by the leadership of the then director of UNESCO, René Maheu, in saving the Abu Simbel monuments from inundation by the Aswan Dam.

Discussions over the next 10 years led to UNESCO, with the support of ICOMOS, developing a concept plan for recognition of monumental sites of cultural endeavour as "sites of universal human value". Then a parallel concept grew up within IUCN that focused upon sites

${ }^{1}$ Charles Sturt University, Albury, N.S.W., Australia

Received/Prejeto: 19.06.2006 
of exceptional natural value. These two somewhat different plans were then integrated, and in 1972, the World Heritage Convention was established as an international agreement, and implemented through UNESCO.

Since then, 788 sites have been assessed and judged worthy of inclusion on the World Heritage Register. Most are recognised as either cultural or natural, but the number that are recognised as having both cultural and natural values has increased and a further category of sites called cultural landscapes has gradually grown up since 1993.
A number of international conventions or other arrangements have arisen to further world stewardship of important values - including the 1971 Ramsar Convention on Wetlands the 1968 Man and Biosphere program, 1982 Charter for Nature, 1992 Convention on Biological Diversity,. The most recent initiative is the Geoparks program which is currently being developed in order to give special recognition to geological phenomena. This program seeks not only to ensure protection of sites of special geological interest, but to further public education.

\section{THE BASIS OF WORLD HERITAGE INSCRIPTION}

The over-riding principle upon which World Heritage inscription is based lies in the concept of "outstanding universal value". The convention states that this means "cultural and/or natural significance which is so exceptional as to transcend national boundaries and to be of common importance for present and future generations of all humanity. As such, the permanent protection of this heritage is of the highest importance to the international community as a whole".

The detailed criteria for the definition of both cultural and natural heritage and for the determination of outstanding universal value are currently under review (UNESCO World Heritage Centre 2003). Under the proposed new guidelines, the two separate sets of criteria for Cultural and Natural Heritage are replaced by a single series. Criteria (i) to (v) are specific to cultural heritage; criteria (vi) is specific to cultural landscapes and is generally used where both cultural and natural values are of significance; natural heritage is dealt with in criteria (vii) to $(\mathrm{x})$. However, in integrating all the criteria into a single list, it is hoped to achieve a greater commonality and integration between natural and cultural heritage and to encourage more comprehensive assessment and nomination.

These are followed by a Statement of Conditions of Integrity and also a statement of the managerial requirements which must be meant prior to inscription. I emphasise the importance of these two sets of conditions. In my experience, they may provide a significant barrier to inscription, or if accepted without critical examination may create difficulties in future attempts to enhance the quality of management. Selected extracts from the new proposals are attached below as Annex 1.

We must also note another important trend is that, where appropriate, serial (or cluster) nominations of a group of similar sites will be preferred to a series of discrete nominations for such sites. In some cases, this may be treated as a boundary extension of an existing site, and it may also give rise to a trans-national site.

\section{OBLIGATIONS OF THE HOST NATION}

On nominating a site for World Heritage recognition, state parties undertake a number of obligations, of which the two must important at the site level are:

- Proper protection and maintenance of the site, and in particular, the values upon which registration is based

- Making access to the site available as a right to all peoples of the world

At first sight, these two sets of obligations are conflicting. Providing access often leads to degradation of a site, but that is largely the case where understanding and management capacity is limited. World experience now demonstrates that sites can and should be managed on a low-impact, high-sustainability basis. The tourism industry must learn to share in and contribute to this level of management.

As a simple example, there is now a lot of understanding of how walkways can be constructed in such a way as to minimise the impacts of infrastructure. But the application of this and related understandings depends upon quality of management. It might even be said that tourists do not create undesirable impacts - but managers do. 


\section{WORLD HERITAGE AND THE CURRENT RECOGNITION OF KARST}

This paper will now focus upon karst sites and discuss some of the issues associated with these. Worldwide, there are some 50 sites that are located upon and/or feature karst phenomena (See Annex 1). Some of these were inscribed for other reasons - but that is not surprising. On one hand, many biodiversity hotspots are located on karst and on the other, the natural beauty of karst often leads to the development of important cultural traditions on karst. A comprehensive list is attached as Annex 2.

The Task Force assumes a holistic perception of karst systems, probably first spelled out explicitly by Yuan Daoxian (1988) and expressed concisely but elegantly by Eberhard (1994) as a system:

... which incorporates component landforms, life, energy flows, water, gases, soils and bedrock.

A particularly useful set of formal (English language) definitions are provided by Lowe and Waltham (2002). A valuable source of translations to other languages can be found on the WWW site of the International Union of Speleology at <http://www.uisic.uis-speleo.org/lexintro. html>.

One only has to look over the list of WH sites to see that a number of themes are important:

- Aesthetic quality: many of the listed sites are famous for their spectacular scenery or the remarkable underground beauty of the caves

- Biodiversity: the biodiversity of karst is utterly remarkable, even if often overlooked - many of those interested in biodiversity focus upon fur, feathers and flowers and ignore the remarkable adaptation, endemicity and diversity of invertebrate populations. The biodiversity upon karst is very much a result of the multitude of micro-climatic niches that are provided both on the surface and underground.

- Geo-climatic and environmental history: "Caves are the books in the library of the history of the earth". As we learn to read the language of the caves more fully, we realise that they really are a remarkable treasure house of our past. Fossils, rock art and sediments provide evidence of particular importance. Further, the patterns of limestone deposition and subsequent karstification tell us a great deal about sea-level change phenomena. In particular, caves are also a major source of geo-climatic history.

- Mineral chemistry: the beauty of cave minerals has long been recognised, but caves now provide valuable natural laboratories for exploring geodiversity and the role of micro-biota in genesis and development of minerals. Recent years have also revealed the immense diversity of stromatolites in karst areas - a life-form once thought to be long extinct.

Evidence of human use and occupation: The most obvious examples are the caves with rock art which is both extremely beautiful and also provides evidence for improving our understanding of the way in which human perceptual and conceptual processes evolved. Today, new discoveries are reported virtually every week. As I sat down to write an earlier version of this paper, my incoming e-mail reported on a British cave art discovery of great significance. More important still, we have just heard the first public announcement of the Homo florensis discovery.

\section{SOME PROBLEMS}

Karst commonly gives rise to some problems in World Heritage assessment.

- Many cave sites are of both cultural and natural significance but the process of assessment has often assumed only one of these to be significant and ignored the other. A number of sites already inscribed warrant further review to broaden the terms of reference for their inclusion. This is an important issue and not just a technicality. If the full significance of the site is not detailed in its citation, then both management planning and future management practice may be unaware of or ignore the unstated values.

- Traditionally, the conservation movement has focused on visible biodiversity or what can be commonly referred to as fur, feathers and flowers. Regrettably the subterranean karst has none of these characteristics, but may have particularly significant biodiversity in the resident invertebrate community. Even when this is spelled out in nomination or similar documents, it may not be accorded the significance that it properly deserves.

- A related problem is that the extremely strong focus on biodiversity tends to push aside important considerations of geodiversity. Consideration is currently being given developing a world network of geoparks and while this is a valuable proposal in itself, it may also mean geodiversity will be even more ignored within the World Heritage family. 


\begin{tabular}{|c|c|}
\hline Theme & Specific Characteristics \\
\hline Overall Context of the Karst System & $\begin{array}{l}\text { Regional context, continental, coastal or island situation; lithology, } \\
\text { structure, stratigraphy, morphogenetic context, geomorphic history. }\end{array}$ \\
\hline Landform Geodiversity & $\begin{array}{l}\text { Enclosed depressions, such as dolines, uvalas, poljes, blind valleys, } \\
\text { gorges, cones, towers, case hardening, karren (both bare rock and } \\
\text { covered forms), assemblages. } \\
\text { Hydrologic features such as sinking streams, springs, estavelles, } \\
\text { hot springs, submarine springs, turloughs. Depositional landforms } \\
\text { such as phytokarst, tufa and travertines, mound springs, terraces, } \\
\text { stromatolites. }\end{array}$ \\
\hline Groundwater Systems and meteorology & $\begin{array}{l}\text { Flow patterns, sinks and springs. Atmospheric and climatic patterns, } \\
\text { including microclimates. }\end{array}$ \\
\hline Subterranean landforms, primarily caves & $\begin{array}{l}\text { Varying plan and cross-sectional patterns, relation to aquifer, genetic } \\
\text { types of caves, age of caves, depth and length of caves. }\end{array}$ \\
\hline Cave Contents & $\begin{array}{l}\text { Sediments, clastic fills, precipitates, types of speleothems. Stratigraphy } \\
\text { of fills. Dating potentials. Palaeontology, archaeology, other cultural } \\
\text { relics or modifications. }\end{array}$ \\
\hline Surface Biodiversity & $\begin{array}{l}\text { Surface flora and fauna. Invertebrates of terrestrial, freshwater and } \\
\text { anchialine environments. Microbiota, including nanobacteria, bacteria, } \\
\text { protozoa, algae. Issues of speciation, adaptation, and endemism. }\end{array}$ \\
\hline Subsurface Biodiversity & $\begin{array}{l}\text { Subterranean flora and fauna, including vertebrates, invertebrates and } \\
\text { microbiota. Speciation, adaptation, endemism. }\end{array}$ \\
\hline $\begin{array}{l}\text { Cultural, religious, historical and } \\
\text { archaeological values }\end{array}$ & $\begin{array}{l}\text { Residence, spiritual or religious, artistic, refuges. Recreation and } \\
\text { tourism, aesthetics. Research and education. }\end{array}$ \\
\hline Negative human impacts & $\begin{array}{l}\text { Damage to or fragmentation of system. } \\
\text { Modification for human use - design quality and impacts. Invasive } \\
\text { species impacts. } \\
\text { Production, sanatoria, defiance, water supply cheese, mushrooms. } \\
\text { Pollution and sedimentation. } \\
\text { Hazards and health issues. } \\
\text { Birds nest collection, Guano extraction. }\end{array}$ \\
\hline Ensuring integrity & $\begin{array}{l}\text { Allogenic catchment condition draining into karst. Monitoring and } \\
\text { control of environment. Management policies and quality. }\end{array}$ \\
\hline
\end{tabular}

Table 1: Draft Evaluation and Assessment Hierarchical Framework

- The biodiversity of many karst areas is indeed striking. It may include a high level of plant endemism on the surface, bats or other vertebrates within the cave, terrestrial, freshwater or anchialine invertebrates and a host of microbiota. In many countries (but much less in Europe) the lack of adequate taxonomic work creates problems in site assessment. Much surface biodiversity simply reflects the geodiversity of underlying rock and soils or of microclimates. But in karst one often finds a high degree of biodiversity in what appears to be a relatively uniform environment, e.g., there are over 50 species of troglobitic dytiscid beetles described from the deeply buried calcretes of Western Australia.

- Criterion (iii) raises a specific problem, most countries with significant karst areas can claim sites of great aesthetic value and many such sites are already inscribed. The proposal from France (2000) did not, however, so much give rise to questions on this basis but rather because of problems relating to integrity and management. I know it is now in the process of being reviewed and resubmitted.

- Virtually any major karst area is likely to meet criteria (vii) and (viii). So the relative importance becomes a major issue. The current movement towards clarifying policies for future nomination has placed a strong emphasis on the definition of classes of sites and then of selecting the best example(s) from each class. Establishing such a list of classes is currently in progress but will probably take another twelve months to achieve a useful result. 
- From a scientific perspective most important yet most neglected component of most caves is the floor. It may well be relatively unattractive but often contains the records of past geoclimatic change, surface vegetation, human and animal succession, geological history and, in itself, is often a valuable biological habitat. If a floor has long been trampled, consideration should be given to an elevated walkway and to an attempt to restore the qualities of the floor surface.

- The very complexity of karst often poses difficulties in assessment. The use of a hierarchical framework is increasingly recognised and the example in Table 1 is drawn from the Proceedings of the Asia Pacific Forum (Wong et al 2001).

\section{KARST WHAS IN EUROPE.}

We commence with a table of the currently inscribed sites.
- I understand that there has been consideration of an alpine karst nomination. It appears to me that a trans-

\begin{tabular}{|l|l|l|}
\hline Hungary / Slovakia & Caves of Aggtelek \& Slovak Karst & vii \\
\hline Slovenia & Škocjanske Jame & viii, ix \\
\hline Bulgaria & Pirin National Park & vii, viii, ix \\
\hline France / Spain & Pyrennes / Mt Perdu & iii, iv, v, vii, ix \\
\hline Russian Federation & Lake Baikal & vii, viii, ix, $\mathrm{x}$ \\
\hline Russian Federation & Western Caucasus & vii, viii, ix, $\mathrm{x}$ \\
\hline Turkey & Pamukkale & iii, iv, ix \\
\hline Yugoslavia : Montenegro & Durmitor National Park & vii, viii, $\mathrm{x}$ \\
\hline France & Caves of the Vézère & i, iii \\
\hline Spain & Altamira & i, iii \\
\hline Spain & Atapuerca & iii, iv \\
\hline Sweden & Södra Ölands Odlingslandskap & iv, $\mathbf{~}$ \\
\hline
\end{tabular}

Table 2: Current European Karst World Heritage Sites

In summary, six sites are inscribed only as natural heritage, three as cultural heritage, one as a cultural landscape and only two as both. At first sight these sites appear to be each satisfactorily defined and cited - but some state parties may wish to raise questions about changes to their boundaries or citations.

A further question is whether other nominations may be proposed:

- I have already noted the potential opportunity for resubmission of the French nomination of highly decorated caves. boundary and possibly serial nomination should be considered rather than any multiple nationally based sites. The essential unity of the Alps should not be fragmented by political boundaries.

- Some types of karst not currently represented on the register include the sulphur-based karst adjacent to the Black Sea, karst in gypsum or halite and sites that demonstrate aspects of Neanderthal cultural behaviour.

Finally, I wish you all well in your efforts to ensure proper protection of karst sites. As chair of the IUCN task force, I will certainly be glad to assist you all in any way we can. 


\section{REFERENCES}

Eberhard, R., 1994: Inventory and Management of the Junee River Karst system, Tasmania. Pp. 8., Forestry Tasmania, Hobart.

Hamilton-Smith, E., 2006: Spatial planning and protection measures for Karst areas. Acta carsologica, 35, 2, 5-11, Ljubljana

Lowe, D. \& Waltham, T. (eds.), 2002: A Dictionary of Karst and Caves. BCRA Cave Studies Series, 10, 140.

UNESCO World Heritage Centre. 2003: Operational Guidelines for the Implementation of the World Heritage Convention (Draft for limited circulation).
UNESCO, Intergovernmental Committee for the Protection of the World Cultural and Natural Heritage, Paris.

Yuan, D.,1988: On the Karst Environmental System. Proceedings of the IAH 21st Congress. Vol. 1, 30-46, Guilin.

Wong, T. \& Hamilton-Smith, E. \& Chape, S. \& Friederich, H., 2001: Proceedings of the Asian-Pacific Forum on Karst Ecosystems and WorldHeritage. Pp. 43, Environment Australia, Canberra.

\section{ANNEX 1: SELECTED EXTRACTS FROM OPERATIONAL GUIDELINES FOR THE IMPLEMENTATION OF THE WORLD HERITAGE CONVENTION (2003)}

\section{AN OVER-RIDING PRINCIPLE}

Cultural and natural heritage must be of "outstanding universal value" to be inscribed on the World Heritage List.

"Outstanding universal value" means cultural and/ or natural significance which is so exceptional as to transcend national boundaries and to be of common importance for present and future generations of all humanity. As such, the permanent protection of this heritage is of the highest importance to the international community as a whole.

\section{DEFINITION OF WORLD HERITAGE}

I.C.1 The criteria for including properties in the World Heritage List should be applied in a way that is consistent with the definition of the cultural and natural heritage set out in Articles 1 and 2 of the World Heritage Convention, as reproduced below.

\section{ARTICLE 1}

For the purposes of this Convention, the following shall be considered as "cultural heritage";

monuments: architectural works, works of monumental sculpture and painting, elements or structures of an archaeological nature, inscriptions, cave dwellings and combinations of features, which are of outstanding universal value from the point of view of history, art or science;

groups of buildings: groups of separate or connected buildings which, because of their architecture, their homogeneity or their place in the landscape, are of outstanding universal value from the point of view of history, art or science;

sites: works of man or the combined works of nature and of man, and areas including archaeological sites which are of outstanding universal value from the historical, aesthetic, ethnological or anthropological points of view.

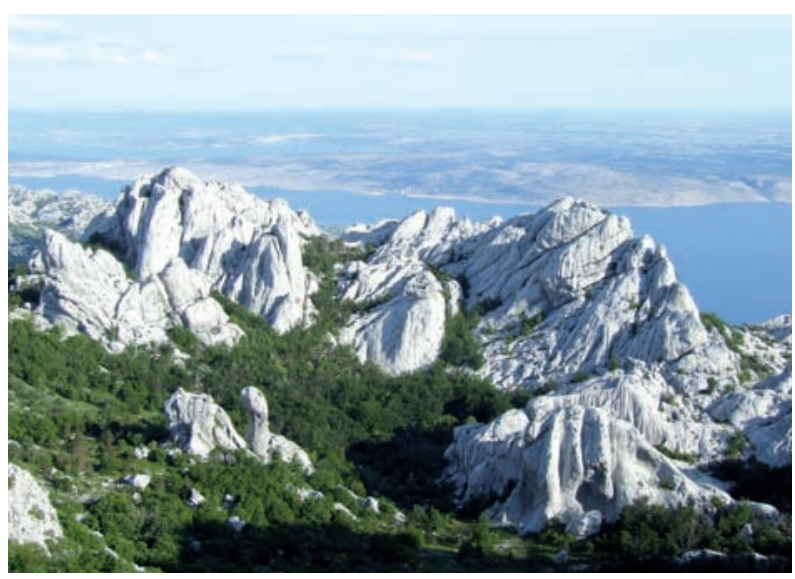

Fig. 1: Velebit Mt., an important and typical part of Dinaric karst (photo N. Zupan Hajna).

\section{ARTICLE 2}

For the purposes of this Convention, the following shall be considered as "natural heritage".: 
natural features consisting of physical and biological formations or groups of such formations, which are of outstanding universal value from the aesthetic or scientific point of view;

geological and physiographical formations and precisely delineated areas which constitute the habitat of threatened species of animals and plants of outstanding universal value from the point of view of science or conservation;

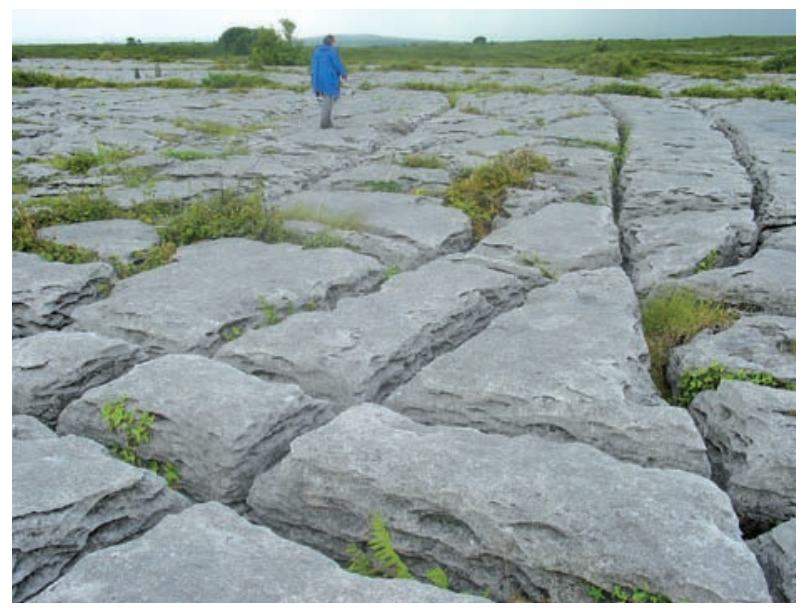

Fig. 2: Limestone pavement, an example from Ireland shown on the picture, is a typical form of karst and needs a special protection (photo A. Kranjc).

\section{CRITERIA FOR DETERMINING OUTSTANDING UNIVERSAL VALUE}

ILC.2 A property which is nominated for inclusion in the World Heritage List will be considered to be of outstanding universal value when the Committee finds that it meets one or more of the following criteria:

(i) represent a masterpiece of human creative genius;

(ii) exhibit an important interchange of human values, over a span of time or within a cultural area of the world, on developments in architecture or technology, monumental arts, town-planning or landscape design;

(iii) bear a unique or at least exceptional testimony to a cultural tradition or to a civilization which is living or which has disappeared;

(iv) is an outstanding example of a type of building, architectural or technological ensemble or landscape which illustrates (a) significant stage(s) in human history;

(v) is an outstanding example of a traditional human settlement, land-use, or sea-use which is representative of a culture (or cultures), or human interaction with the environment especially when it has become vulnerable under the impact of irreversible change; (vi) be directly or tangibly associated with events or living traditions, with ideas, or with beliefs, with artistic and literary works of outstanding universal significance. The Committee considers that this criterion should preferably be used in conjunction with other criteria;

(vii) contain superlative natural phenomena or areas of exceptional natural beauty and aesthetic importance.

(viii) be outstanding examples representing major stages of earth's history, including the record of life, significant on 7 going geological processes in the development of landforms, or significant geomorphic or physiographic features;

(ix) be outstanding examples representing significant on-going ecological and biological processes in the evolution and development of terrestrial, fresh water, coastal and marine ecosystems and communities of plants and animals;

(x) contain the most important and significant natural habitats for in-situ conservation of biological diversity, including those containing threatened species of outstanding universal value from the point of view of science or conservation;

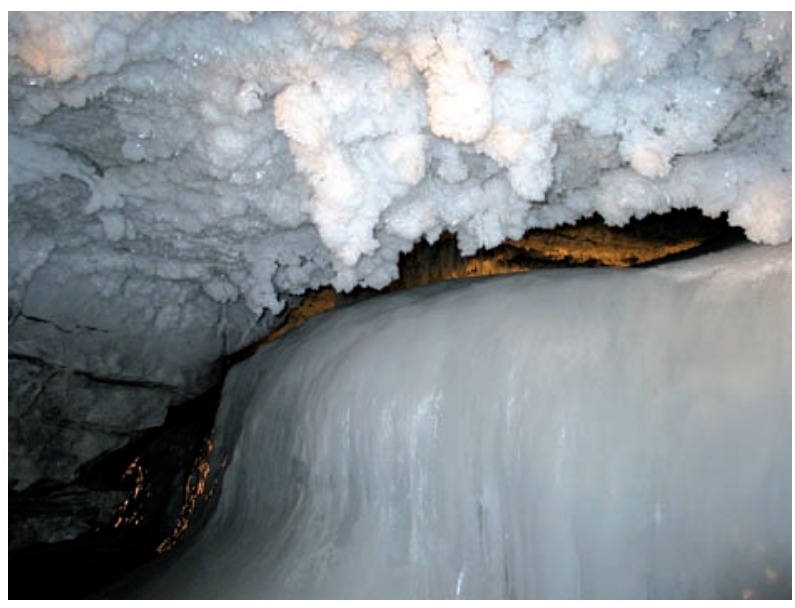

Fig. 3: Regarding the ice formation, the history and the long sequence of scientific observations, Kungur Ice Cave has the World importance (photo A. Kranjc).

\section{CONDITIONS OF INTEGRITY}

ILD.9 Integrity is a measure of the wholeness and intactness of the natural and/or cultural heritage and its attributes. Examining the conditions of integrity, therefore, requires assessing whether or not the property:

- includes all elements necessary to express its outstanding universal value;

- is of adequate size to ensure the complete representation of the features and processes which convey the property's significance; 
- is free from the adverse effects of development and/or neglect.

II.D.10 For properties nominated under criteria (i) to (vi), the physical fabric of the property and/or its significant features should be in good condition, and the impact of deterioration processes controlled. A significant proportion of the elements necessary to convey the totality of the value conveyed by the property should be included. Relationships and dynamic functions present in cultural landscapes, historic towns or other living properties essential to their distinctive character should also be maintained.

ILD.11 For all properties nominated under criteria (vii) to (x), bio-physical processes and landform features should be relatively intact. However, it is recognized that no area is totally pristine and that all natural areas are in a dynamic state, and to some extent involve contact with people. Human activities, including those of traditional societies and local communities, often occur in natural areas. These activities may be consistent with the outstanding universal value of the area where/when they are ecologically sustainable.

II.D.12 In addition, for properties nominated under criteria (vii) to (x), a corresponding condition of integrity has been defined for each criterion.

ILD.13 Properties proposed under criterion (vii) should be of outstanding universal value and include areas that are essential for maintaining the beauty of the property. For example, a property whose scenic value depends on a waterfall, would meet the conditions of integrity if it includes adjacent catchment and downstream areas that are integrally linked to the maintenance of the aesthetic qualities of the property.

ILD.14 Properties proposed under criterion (viii) should contain all or most of the key interrelated and interdependent elements in their natural relationships. For example, an "ice age" area would meet the conditions of integrity if it includes the snow field, the glacier itself and samples of cutting patterns, deposition and colonization (e.g. striations, moraines, pioneer stages of plant succession, etc.); in the case of volcanoes, the magmatic series should be complete and all or most of the varieties of effusive rocks and types of eruptions be represented.

ILD.15 Properties proposed under criterion (ix) should have sufficient size and contain the necessary elements to demonstrate the key aspects of processes that are essential for the long-term conservation of the ecosystems and the biological diversity they contain. For example, an area of tropical rain forest would meet the conditions of integrity if it includes a certain amount of variation in elevation above sea-level, changes in topography and soil types, patch systems and naturally regenerating patches; similarly a coral reef should include, for example, seagrass, mangrove or other adjacent ecosystems that regulate nutrient and sediment inputs into the reef.

ILD.16 Properties proposed under criterion (x) should be the most important properties for the conservation of biological diversity. Only those properties which are the most biologically diverse and/or representative are likely to meet this criterion. The properties should contain habitats for maintaining the most diverse fauna and flora characteristic of the bio-geographic province and ecosystems under consideration. For example, a tropical savannah would meet the conditions of integrity if it includes a complete assemblage of co-evolved herbivores and plants; an island ecosystem should include habitats for maintaining endemic biota; a property containing wide-ranging species should be large enough to include the most critical habitats essential to ensure the survival of viable populations of those species; for an area containing migratory species, seasonal breeding and nesting sites, and migratory routes, wherever they are located, should be adequately protected. 


\section{ANNEX 2: WORLD HERITAGE KARST SITES}

A listing initially prepared by Elery Hamilton-Smith and Rolf Hogan, April 2001 (Updated to 2005 by EHS)
Note that the criteria shown are from the earlier separate listings for cultural and natural heritage under which inscription occurred.

\begin{tabular}{|c|c|c|c|c|}
\hline World Heritage Site & $\begin{array}{l}\text { State } \\
\text { Party }\end{array}$ & & Key Features & \\
\hline Tasmanian Wilderness & Australia & 1982 & $\begin{array}{l}\text { Many areas of karst in limestone and dolomite. } \\
\text { High geodiversity and biodiversity values. }\end{array}$ & $\begin{array}{l}\text { i, ii, iii, iv } \\
\text { C iii, v, vi }\end{array}$ \\
\hline Lord Howe Island & Australia & 1982 & $\begin{array}{l}\text { Small area of karst in aeolian calcarenite and } \\
\text { coralline limestones }\end{array}$ & iii, iv \\
\hline $\begin{array}{l}\text { Central Eastern } \\
\text { Rainforests }\end{array}$ & Australia & 1986 & $\begin{array}{l}\text { A large number of relatively small reserves, some } \\
\text { of which include areas of impounded karst }\end{array}$ & $\mathrm{i}, \mathrm{ii}, \mathrm{iv}$ \\
\hline Shark Bay & Australia & 1991 & $\begin{array}{l}\text { Located on karst, with zones of differential } \\
\text { salinity within the bay and outstanding display of } \\
\text { living Stromatolites }\end{array}$ & i, ii, iii, iv \\
\hline $\begin{array}{l}\text { Australian Fossil } \\
\text { Mammal Sites }\end{array}$ & Australia & 1994 & $\begin{array}{l}\text { Vertebrate Fossil deposits at Riversleigh } \\
\text { (Oligocene-Miocene) \& Naracoorte (Pleistocene). } \\
\text { Both have a diversity of karst landforms and } \\
\text { Naracoorte has high current biodiversity. }\end{array}$ & $\mathrm{i}, \mathrm{ii}$ \\
\hline Greater Blue Mountains & Australia & 2000 & $\begin{array}{l}\text { Includes Jenolan Caves and a number of smaller } \\
\text { karst sites }\end{array}$ & ii, iv \\
\hline Purnululu & Australia & 2003 & $\begin{array}{l}\text { Karst landscape on quartzitic sandstones } \\
\text { demonstrating clearly the process of cone karst } \\
\text { formation on sandstone }\end{array}$ & i, iii \\
\hline Pirin National Park & Bulgaria & 1983 & $\begin{array}{l}\text { Various areas of karst, some of which have been } \\
\text { shaped by glaciation }\end{array}$ & i, ii, iii \\
\hline Nahanni National Park & Canada & 1978 & $\begin{array}{l}\text { Spectacular karst landforms, including an } \\
\text { immense gorge and caves }\end{array}$ & ii, iii \\
\hline Canadian Rockies & Canada & 1984 & Includes Castleguard and other caves & i, ii, iii \\
\hline Zhoukoudian & China & 1987 & $\begin{array}{l}\text { Peking Man excavation site situated in ancient } \\
\text { karst }\end{array}$ & C iii, iv \\
\hline $\begin{array}{l}\text { Wulingyuan Scenic and } \\
\text { Historic Interest Area }\end{array}$ & China & 1992 & $\begin{array}{l}\text { At least one-third of the site is on limestone, with } \\
\text { extremely large caves and two natural bridges, one } \\
\text { of which is } 357 \mathrm{~m} \text {. high. }\end{array}$ & iii \\
\hline Huanglong & China & 1992 & $\begin{array}{l}\text { Famous for its extensive and spectacular } \\
\text { travertine deposits; many other karst features }\end{array}$ & iii \\
\hline Jiuzhaigou Valley & China & 1992 & Largely on dolomite with calcareous travertine & iii \\
\hline $\begin{array}{l}\text { Three Parallel Rivers of } \\
\text { Yunnan Karst }\end{array}$ & China & 2003 & $\begin{array}{l}\text { Geological history of the last } 50 \text { million years } \\
\text { associated with the collision of the Indian Plate } \\
\text { with the Eurasian Plate, the closure of the ancient } \\
\text { Tethys Sea, and the uplifting of the Himalaya } \\
\text { Range and the Tibetan Plateau. }\end{array}$ & i, ii, iii, iv \\
\hline
\end{tabular}




\begin{tabular}{|c|c|c|c|c|}
\hline $\begin{array}{l}\text { Plitvice Lakes National } \\
\text { Park }\end{array}$ & & $\begin{array}{l}1979 \\
2000\end{array}$ & $\begin{array}{l}\text { Spectacular travertine barriers and lake systems; } \\
\text { forest in excellent condition. }\end{array}$ & ii, iii \\
\hline Viñales Valley & Cuba & 1999 & $\begin{array}{l}\text { Karst landscape with conical hills (Mogotes) in } \\
\text { a wide flat-floored valley. It is a 'type locality' } \\
\text { of Mogote karst and has a rich subterranean } \\
\text { biodiversity. }\end{array}$ & C iv \\
\hline $\begin{array}{l}\text { Desembarco del Granma } \\
\text { National park and System } \\
\text { of Marine Terraces of } \\
\text { Cabo Cruz }\end{array}$ & Cuba & 1999 & $\begin{array}{l}\text { Uplifted marine terraces and ongoing } \\
\text { development of karst topography. Aesthetic value } \\
\text { of stair-step terraces and cliffs }\end{array}$ & i, iii \\
\hline $\begin{array}{l}\text { Alejandro de Humboldt } \\
\text { National Park }\end{array}$ & Cuba & 2001 & $\begin{array}{l}\text { A large inland plateau which is one of the most } \\
\text { biologically diverse island sites known. It includes } \\
\text { both limestone karst and pseudokarst }\end{array}$ & ii, iv \\
\hline Caves of the Vézère & France & 1979 & $\begin{array}{l}\text { Some } 147 \text { identified and significant prehistoric } \\
\text { sites, including the famous Lascaux and many } \\
\text { other painted caves }\end{array}$ & $\mathrm{C}$ i, iii \\
\hline Pyrenees-Mount Perdu & France/Spain & $\begin{array}{l}1997 \\
1999\end{array}$ & $\begin{array}{l}\text { Alpine karst site with lakes, gorges, waterfalls, } \\
\text { cirques and canyons }\end{array}$ & $\begin{array}{l}\text { i, iii } \\
\text { C iii, iv, v }\end{array}$ \\
\hline $\begin{array}{l}\text { Caves of Aggtelek and } \\
\text { Slovak Karst }\end{array}$ & $\begin{array}{l}\text { Hungary/ } \\
\text { Slovakia }\end{array}$ & $\begin{array}{l}1995 \\
2000\end{array}$ & $\begin{array}{l}712 \text { caves. Variety and concentration of cave } \\
\text { types, speleothems and an array of typical } \\
\text { temperate zone karst features. (Includes aragonite } \\
\text { and sinter formations and an ice filled abyss.) }\end{array}$ & $\mathrm{i}$ \\
\hline Lorentz National Park & Indonesia & 1999 & $\begin{array}{l}\text { Much of the park is high altitude karst, with } \\
\text { spectacular landforms. Regrettably, the finest of } \\
\text { the karst is adjacent to but not yet included in the } \\
\text { park }\end{array}$ & i, ii, iii, iv \\
\hline Luang Prabang & Laos & 1995 & $\begin{array}{l}\text { Built on karst with various landforms; a number } \\
\text { of the caves are important temple sites. }\end{array}$ & C ii, iv, v \\
\hline Tsingy de Bemaraha & Madagascar & 1990 & $\begin{array}{l}\text { Pinnacle karst that is difficult to access; little } \\
\text { investigation to date. }\end{array}$ & iii, iv \\
\hline Gunung Mulu & Malaysia & 2000 & $\begin{array}{l}295 \mathrm{~km} \text { explored caves, Sarawak Chamber } \\
\text { - world's largest; Speleothems with spectacular } \\
\text { aragonite \& calcite needles. } 1.5 \text { myo sediment } \\
\text { sequence, giant doline-karst collapse, lateral } \\
\text { planation; Bats \& swiftlets energy transfer from } \\
\text { forest to cave; Karst, bats, pinnacle forest Forest \& } \\
\text { cave biodiversity. }\end{array}$ & i, ii, iii, iv \\
\hline Chichen Itza & Mexico & 1988 & $\begin{array}{l}\text { Religious Centre, situated around an immense } \\
\text { cenote that was a major site of sacrificial rituals }\end{array}$ & C I, ii, iii \\
\hline Luang Prabang & Laos & 1995 & $\begin{array}{l}\text { Built on karst with various landforms; a number } \\
\text { of the caves are important temple sites. }\end{array}$ & $\mathrm{C}$ ii, iv, v \\
\hline Sian Kảan & Mexico & 1987 & $\begin{array}{l}\text { Situated on the edge of the great cenote karst of } \\
\text { the Yucatan Peninsula. Only a small part of this } \\
\text { karst is within the WHA. }\end{array}$ & iii, iv \\
\hline Te Wahipounamu & New Zealand & 1990 & $\begin{array}{l}\text { Includes a number of small areas of karst, } \\
\text { including the Aurora Cave at Te Anau. }\end{array}$ & i, ii, iii, iv \\
\hline
\end{tabular}




\begin{tabular}{|c|c|c|c|c|}
\hline $\begin{array}{l}\text { Puerto-Princesa } \\
\text { Subterranean River } \\
\text { National Park }\end{array}$ & Philippines & & $\begin{array}{l}\text { Spectacular karst landscape, underground river } \\
\text { \& caves. Most significant forest in Palawan } \\
\text { Biogeographical Province. }\end{array}$ & iii, iv \\
\hline Lake Baikal & $\begin{array}{l}\text { Russian } \\
\text { Federation }\end{array}$ & 1996 & $\begin{array}{l}\text { A major part of the watershed (Irkutsk basin) is } \\
\text { located on Karst. }\end{array}$ & i, ii, iii, iv \\
\hline Western Caucasus & $\begin{array}{l}\text { Russian } \\
\text { Federation }\end{array}$ & 1999 & $\begin{array}{l}\text { The Northern section consists entirely of karst } \\
\text { with some of the world's great deep and extensive } \\
\text { caves. Some of these have important Neanderthal } \\
\text { sites and so are of considerable archaeological } \\
\text { value. }\end{array}$ & i, ii, iii, iv \\
\hline Škocjanske Jame & Slovenia & 1986 & $\begin{array}{l}\text { Awesome river canyons, textbook portrayal of } \\
\text { karst hydrogeology. On-going process; Collapsed } \\
\text { dolines \& caverns . }\end{array}$ & ii, iii \\
\hline East Rennell & $\begin{array}{l}\text { Solomon } \\
\text { Islands }\end{array}$ & 1998 & A particularly large and diverse raised coral atoll. & ii \\
\hline $\begin{array}{l}\text { The Fossil Hominid } \\
\text { Sites of Sterkfontein, } \\
\text { Swartkrans, Kromdraai, } \\
\text { and Environs }\end{array}$ & South Africa & 1999 & $\begin{array}{l}\text { A cluster of karst sites containing remains of some } \\
\text { of the earliest humanoids. }\end{array}$ & C iii, iv \\
\hline Altamira Cave & Spain & 1985 & $\begin{array}{l}\text { One of the most famous and diverse collections of } \\
\text { cave art }\end{array}$ & $\mathrm{C}$ i, iii \\
\hline Atapuerca Caves & Spain & 2000 & $\begin{array}{l}\text { Contains earliest and richest evidence of human } \\
\text { beings in Europe. }\end{array}$ & C iii, iv \\
\hline $\begin{array}{l}\text { Södra Ölands } \\
\text { Odlingslandskap }\end{array}$ & Sweden & 2000 & $\begin{array}{l}\text { The only extensive area of limestone in Sweden } \\
\text { - a large pavement with various surface karst } \\
\text { features. }\end{array}$ & $\mathrm{C}$ iv,v \\
\hline $\begin{array}{l}\text { Thung Yai Hua Kha } \\
\text { Khaeng }\end{array}$ & Thailand & 1991 & $\begin{array}{l}\text { One of the various protected areas over the } \\
\text { Western karst region - an area with great diversity } \\
\text { and value on many criteria. }\end{array}$ & ii, iii, iv \\
\hline Pamukkale & Turkey & 1988 & Spectacular travertine terraces & $\begin{array}{l}\text { iii } \\
\text { C iii, iv }\end{array}$ \\
\hline Henderson Island & $\begin{array}{l}\text { UK: Pitcairn } \\
\text { Islands }\end{array}$ & 1988 & $\begin{array}{l}\text { Relatively undisturbed example of a raised coral } \\
\text { atoll. }\end{array}$ & iii, iv \\
\hline Grand Canyon & USA & 1979 & $\begin{array}{l}\text { Caves are found throughout the Redwall } \\
\text { limestone beds and contain a great number of } \\
\text { archaeological relics. }\end{array}$ & i, ii, iii, iv \\
\hline $\begin{array}{l}\text { Mammoth Cave National } \\
\text { Park }\end{array}$ & USA & 1981 & $\begin{array}{l}\text { Continuous cave formation ( } 100 \text { mya-present). } \\
\text { Large level passages \& jagged domepits. Rich } \\
\text { troglobitic fauna. }\end{array}$ & i,iii,iv \\
\hline $\begin{array}{l}\text { Carlsbad Caverns } \\
\text { National Park }\end{array}$ & USA & 1995 & $\begin{array}{l}81 \text { caves. Huge caverns \& decorative mineral } \\
\text { features, scenic values esp. Lechuguilla. (Most } \\
\text { types of limestone cave formation are found here, } \\
\text { including long passages with huge chambers, } \\
\text { vertical shafts, stalagmites, stalactites and gypsum } \\
\text { 'flowers' and 'needles'. Excellent examples of } \\
\text { karstification by sulphur acids. Rich microfauna.) }\end{array}$ & i, iii \\
\hline Canaima National Park & Venezuela & 1994 & $\begin{array}{l}\text { The most outstanding example in the world of } \\
\text { karst in quartzitic sandstones. }\end{array}$ & i, ii, iii, iv \\
\hline
\end{tabular}




\begin{tabular}{|l|l|c|l|l|}
\hline Ha Long Bay & 1994 & $\begin{array}{l}\text { Most extensive and best-known example of } \\
\text { marine invaded tower karst and one of the most } \\
\text { important areas of fengcong and fenglin karst in } \\
\text { the world. }\end{array}$ & i, ii \\
\hline Phong Nha Ke Bang & Vietnam & 2003 & $\begin{array}{l}\text { One of the finest and most distinctive examples } \\
\text { of a complex karst landform in SE Asia. Phong } \\
\text { Nha displays an impressive amount of evidence of } \\
\text { earths history. }\end{array}$ & i \\
\hline Durmitor National Park & Montenegro & 1980 & $\begin{array}{l}\text { Deep limestone beds span a remarkable geological } \\
\text { sequence. Glacial lakes, caves and the Tara } \\
\text { Canyon dominate the landscape. }\end{array}$ & ii,. ii, iv \\
\hline
\end{tabular}




\title{
REPORT FROM THE WORLD HERITAGE MEETING AT CHRISTCHURCH, NEW ZEALAND,
}

\author{
23 JUNE-1 JULY 2007
}

I hope the grapevine has already brought you the good news, but just in case it hasn't, I thought I should write to let you know of considerable- but not unqualified -success concerning cave and karst sites at the World Heritage meeting in New Zealand last week. I did not have the status as an 'observer' at the meeting to be permitted to say anything in the general assembly, but I can assure you that much was said in informal sessions outside of the meeting hall.

The World Heritage Committee showed complete consensus over the World Heritage value of 'Jeju Volcanic Island and Lava Tubes', so that site is now formally inscribed on the WH list.

Kyung Sik Woo, a geologist and caver, did an enormous amount of energetic and highly professional work over several years to ensure the success of that nomination. So both he and South Korea are to be congratulated. We now have some fantastic lava tubes properly recognized and protected.

The World Heritage Committee also reached a clear conclusion over the 'South China Karst' nomination and that is also now inscribed formally on the World Heritage list. This nomination comprised three separate sites: the Shilin 'Stone Forest', the Libo cone karst, and the Wulong tiankeng-natural bridges karst. Shilin and Libo were supported without significant further discussion, but the Wulong site stimulated quite a lot of debate within the World Heritage Committee because the draft recommendation from the IUCN was that approval of the site be deferred (this was not because the IUCN did not recognize its World Heritage qualities but because they considered Furong Cave not to be of WH quality and because the boundaries of the site need further consideration to ensure effective environmental management of the tiankeng, bridges and subterranean ecosystems.

In short, the nomination needed a few amendments in detail and a rationalizing of boundaries to ensure the quality expected of $\mathrm{WH}$ properties).
However, it seems that the World Heritage Committee (composed of politicians, not scientists) considered that inscription could still be accepted in principle, on the understanding that the outstanding management and boundary issues could be cleared up later. I find this pragmatic approach to be entirely acceptable, provided the Chinese authorities really do make the necessary changes. The upshot of all this is that we now have three wonderful karst sites with great caves in China on the World Heritage list. This is just Phase 1 of their serial nomination. Phase 2 will follow in just a few years time with more nominations. There is still debate to come as to what sites might be included, but I am pretty sure that the iconic tower karst between Guilin and Yangshuo along the Li river will be included.

There was another caves and karst World Heritage nomination concerning parts of numerous caves rich in speleothems in France. However, the IUCN did not support the nomination and their draft recommendation was that the sites should not be inscribed on the World List. France chose to withdraw the nomination before it was formally considered by the World Heritage Committee, because that leaves open the possibility of revising the case presented and re-applying at a later date.

An important point concerning the future of cave and karst sites is that there is a feeling amongst the World Heritage Committee and IUCN that caves and karst are now very well represented on the World Heritage List. This means that it will be increasingly difficult to get new sites accepted. However, there is also a recognition that on the Natural World Heritage List in general sites located in the semi-arid and arid zones are not well represented. So there seems to me to be potential there for some new Australian and Brazilian karst sites.

Paul Williams 
